\title{
»Frem, arbejder, frem!«
}

Den danske bevægelse i Nordslesvig og »arbejderspørgsmålet« ca. $1900-1914$

\section{Af Hans Schultz Hansen}

Fra slutningen af $1890^{\circ}$ erne begyndte arbejderbevægelsen så småt at vinde bredere fodfæste i Nordslesvig. Derved opstod et nyt problem for det nationale arbejde. Skulle danske arbejdere lægge mest vægt på de sociale krav og orientere sig i retning af Socialdemokratiet, eller kunne deres interesser bedre varetages af den gårdmandsdominerede danske bevægelse? Forskningsstipendiat Hans Schultz Hansen fortæller her om de forskellige holdninger til de sociale problemer inden for arbejderkredse og $\mathrm{i}$ den etablerede danske bevægelse og om oprettelsen af »Dansk Arbejderforening for Nordslesvigu.

\section{Indledning}

Da udgivelsen af Sønderjyske Årbøger genoptoges efter otte års pause i 1923, fik tidsskriftet som de andre årbøger fra de amtshistoriske samfund i Danmark et rent historisk indhold. I perioden forud, 1889-1914 udgjorde bidrag med aktuelle temaer derimod en stor del af artikelstoffet - hvilket gør disse gamle årgange så interessante for historikeren. I årgang 1913 fandtes f.eks. en artikel med titlen "De danske sønderjyder «. Den var forfattet af årbøgernes hovedredaktør H.P. Hanssen-Norremolle og havde den for en nutidig læser lidt afskrækkende undertitel »Uddrag af den officielle tyske statistik «.

Det lønner sig imidlertid at læse denne afhandling. Dels fremdrager H.P. Hanssen her hovedresultaterne fra den tyske statistiker Max Broesickes undersøgelse af de dansktalende sønderjyder fra 1911, og dels giver han tallene sin personlige, politisk prægede kommentar. Broesickes analyse af folketællingen fra 1905 viste, at der blandt de dansktalende sønderjyder var forholdsvis mange selvstændige sammenlignet med antallet af lønmodtagere. Ifølge H.P. Hanssens udregning var $46 \%$ af de dansktalende, som var beskæftigede $i$ landbrug, håndværk, industri og handel, selverhvervende, mens $54 \%$ var medhjælpere. Disse tal knyttede han følgende kommentar til: »Få landsdele er i virkeligheden nået videre frem imod det lysende ideal, Grundtvig har opstillet, da han skrev: „Og da har i rigdom vi drevet det vidt, når få har for meget og færre for lidt««.'

Hanssen havde også benyttet disse tal i en valgtale i 1911 om "Sunde samfundsforhold - utåleligt landrådsregimente«. I denne tale havde han hæv- 
det, at der i Nordslesvig fandtes nem adgang til socialt avancement: "Dette tal [af lønarbejdere] omfatter tilmed talrige sønner, som arbejder hjemme med sikker udsigt til at blive deres faders efterfølger. Og af de øvrige medhjælpere har de fleste udsigt til med tiden at nå frem til selvstændige stillinger, når de er sparsommelige, ædruelige, flittige og dygtige ${ }^{2}$

I denne artikel er det hensigten at konfrontere H.P. Hanssens opfattelse af Nordslesvig som et samfund præget af social lighed med arbejdernes synspunkter, således som disse kom til udtryk $i$ debatten $i$ den danske presse om »arbejderspørgsmålet« fra århundredskiftet og frem til verdenskrigen. Det skal endvidere belyses, hvordan forholdet mellem arbejderne og den danske nationale bevægelse udviklede sig - kunne det nationale sammenhold på tværs af klasseskellene opretholdes?

\section{Arbejderklasse og arbejderbevægelse i Nordslesvig}

Først skal der imidlertid gives en kort beskrivelse af den nordslesvigske arbejderklasse og den socialdemokratiske arbejderbevægelse.

Max Broesickes analyse af de dansktalende sønderjyder i 1905 havde vist følgende sociale opdeling:

\begin{tabular}{|l|r|c|c|c|c|c|c|}
\hline Socialgruppe & $\begin{array}{c}\text { Land- } \\
\text { brug }\end{array}$ & $\begin{array}{c}\text { Håndværk, } \\
\text { industri }\end{array}$ & $\begin{array}{c}\text { Handel, } \\
\text { samfærdsel }\end{array}$ & $\begin{array}{c}\text { Daglejere, } \\
\text { tyende }^{\mathrm{l}}\end{array}$ & $\begin{array}{c}\text { Frie erhverv, } \\
\text { embedsmænd }^{2}\end{array}$ & Ialt & Pct. \\
\hline Selvstændige & 11031 & 4405 & 2064 & - & & 17500 & 35 \\
Funktionærer & 582 & 96 & 241 & - & 793 & 1712 & 3 \\
Arbejdere & 19064 & 5361 & 1653 & 4044 & - & 30122 & 61 \\
\hline Ialt & 30677 & 9862 & 3958 & 4044 & 793 & 49443 & 100 \\
\hline Pct. & 62 & 20 & 8 & 8 & 2 & 100 & \\
\hline
\end{tabular}

Anm.: 1 Kun de, der ikke havde tilknytning til et af de andre erhverv. Især tjenestepiger $\mathrm{i}$ byerne (3408 var kvinder).

2 Inkl. militære. Alle i gruppen er her regnet som funktionærer, selv om der har været et mindre antal selvstændige læger, tandlæger, dyrlæger, advokater etc.

Kilde: H.P. Hanssen: De danske Sønderjyder, SJy Årb 1913, s. 41 f.

Når forholdet mellem selvstændige og lønmodtagere i tabellen afviger fra H.P. Hanssens tal (se side 287), skyldes det dels, at han i tidens ånd kun regnede med mændene, dels at han kun inddrog landbrug, håndværk-industri og handelsamfærdsel i beregningen.

Den dominerende gruppe i det dansktalende nordslesvigske samfund var gårdejerne, der udgjorde om ved halvdelen af de 11.000 selvstændige i landbruget. De sad solidt på jordressourcerne, idet $74 \%$ af landbrugsjorden tilhørte 


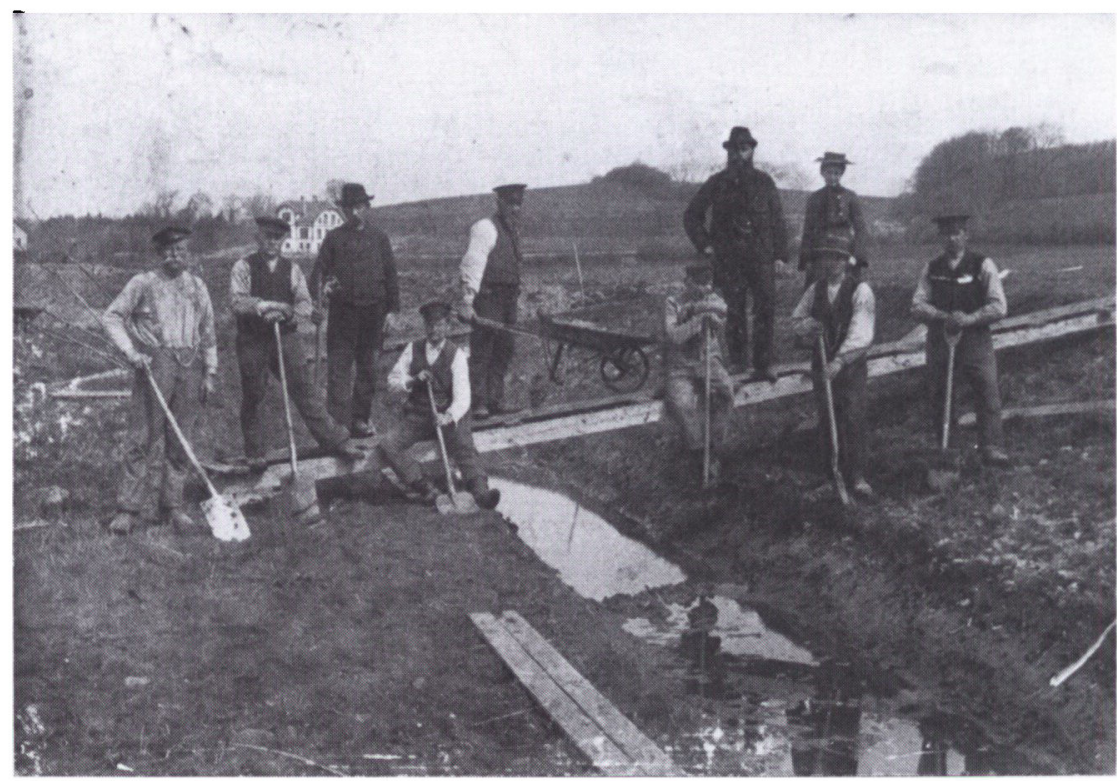

Den nordslesvigske arbejderklasse bestod i ärene efter 1900 af ca. 30.000 mand og kvinder, hvoraf knap 20.000 var landarbejdere. Byernes vakst efter ärhundredskiftet bevirkede imidlertid en betydelig forogelse af byarbejdernes tal. Her ses arbejdere fra Aabenraa beskaftiget med draningsgravning ved Lindsnakkevej i 1902. Nr. 2 fra venstre er Carl Svend Magnusson (1873-1955). Fot. i Historiske Samlinger for Sonderjylland.

ejendomme på over 20 ha. Det gav dem økonomisk uafhængighed, og deres velstand var stigende. ${ }^{3}$

Arbejderklassen udgjordes af 30.000 personer, hvoraf 19.000 som tjenestefolk eller daglejere var $\mathrm{i}$ et direkte afhængighedsforhold til gårdmændene. Mange af tjenestefolkene var dog gårdmandssønner under uddannelse, men til gengæld havde mange af de mindre jordbesiddere lønarbejde som biindtægtskilde, og i det hele taget var de sammen med adskillige mindre håndværkere og handlende ofte ikke stort bedre stillet end arbejderne.

Desværre er Broesickes undersøgelse enkeltstående. Der findes ingen tal fra hverken før eller efter 1905, som kunne bidrage til at tegne en udviklingslinje. To tendenser har dog uden tvivl påvirket også den dansktalende befolknings sociale sammensætning. For det første kan der, selv om der langtfra var tale om noget industrielt gennembrud, konstateres en vækst $i$ antallet af beskæftigede $\mathrm{i}$ industri og håndværk på 20\% fra 1895 til 1907. Samtidig koncentreredes produktionen på færre virksomheder. ${ }^{4}$ For det andet begyndte bybefolkningen at vokse efter lang tids stagnation, fra $19 \%$ af befolkningen $i$ 
1895 til $25 \%$ i 1910 . Denne forøgelse faldt især på arbejderklassen. ${ }^{5}$ Begge disse tendenser gjorde sig utvivlsomt gældende med accelererende kraft frem til verdenskrigen.

Byerhvervenes stagnation frem til midten af 1890 -erne og ikke mindre den enorme udvandring i 1870-erne og 1880-erne havde gjort det vanskeligt for Socialdemokratiet at finde grobund i Nordslesvig. Det sociale pres fra neden var aftagende, og tillige hæmmedes den socialdemokratiske agitation af agitatorernes manglende kendskab til det danske sprog. Helt anderledes var det imidlertid gået i den stærkt voksende industriby Flensborg. Her blev Socialdemokratiet allerede i 1890 byens største parti. Fremgangen var især sket på den danske bevægelses bekostning. Endnu i 1884 havde Gustav Johannsen kunnet mønstre $40 \%$ af stemmerne, i 1890 fik han kun $11 \%$. Kampen mellem danskere og socialdemokrater om den flensborgske arbejderklasses stemmer var definitivt endt med de sidstnævntes sejr. ${ }^{6}$

Efter ophævelsen af Bismarcks antisocialistiske love i 1890 var vejen for den socialdemokratiske agitation atter fri. Der gik dog flere år, før der kunne oprettes partiafdelinger i Nordslesvig, det skete først i Haderslev i 1897, i Sønderborg i 1898 og i Aabenraa i 1901.7 Tilslutningen til Socialdemokratiet ved rigsdagsvalgene steg ligeledes ret langsomt:

Socialdemokratiets procentvise valgerandel ved rigsdagsvalgene 1874-1912

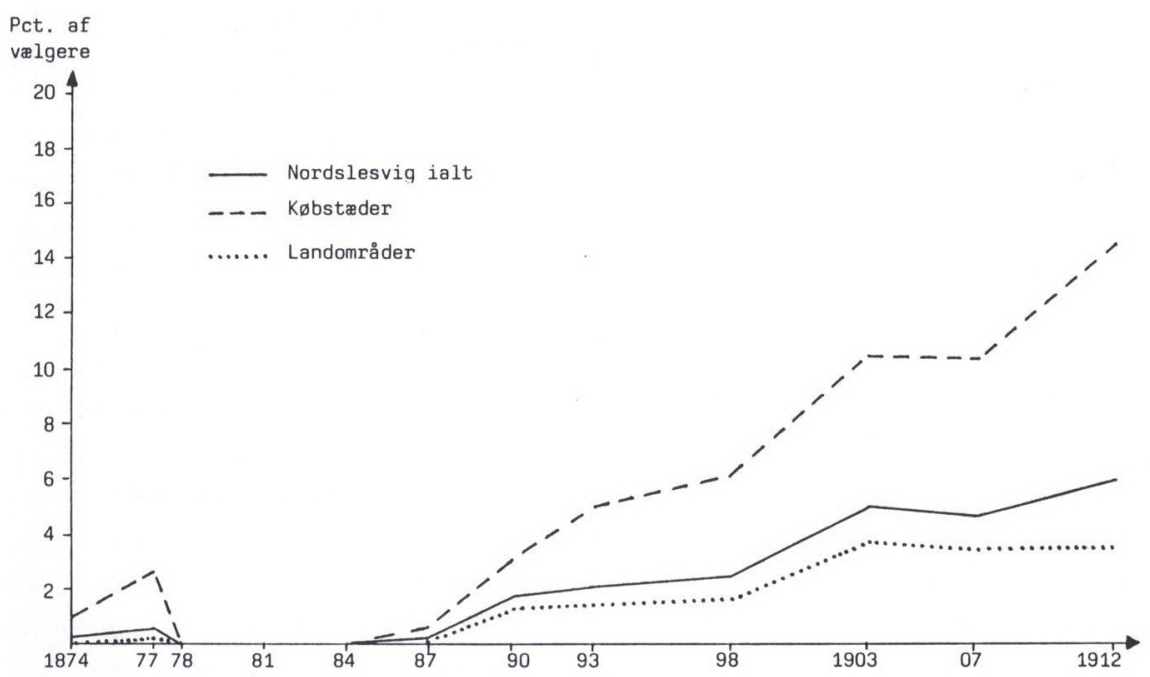

Kilde: Aksel Lassen: Valg mellem tysk og dansk, Ábenrå 1976, s. 417, 428-31. 
Socialdemokratiets fremgang var betydelig ved valgene i 1890 og 1903, mens de øvrige valg nærmest viste stagnation. Særlig på landet forblev tilslutningen beskeden, hvorimod der i byerne var en klar fremgangslinje. Med byernes vækst efter århundredskiftet og deres stigende andel af den samlede nordslesvigske befolkning måtte det forudses, at Socialdemokratiets stilling også $\mathrm{i}$ landsdelen som helhed ville blive vasentligt styrket.

Partiets ønske om at vinde indpas i den nordslesvigske arbejderklasse nødvendiggjorde en klar stillingtagen til det nationale problem. I 1870-erne havde de socialdemokratiske kandidater i ret uforpligtende vendinger udtalt sig for en folkeafstemning om Nordslesvigs genforening med Danmark, men senere ophørte sådanne udtalelser. Derimod havde partiets kritik af myndighedernes, frem for alt overpræsident von Köllers undertrykkelse af den danske bevægelse været konsekvent, og rigsdagsgruppens støtte til den danske repræsentant Gustav Johannsen havde været værdifuld.

Socialdemokratiets grænsepolitik blev imidlertid præciseret på det slesvigholstenske socialdemokratis partidag i Flensborg i 1902. I en resolution

I ḋrene efter århundredskiftet foretog det slesvig-holstenske socialdemokrati et agitationsfremsted $i$ Nordslesvig. Fra 1904 udgav partiet sảledes en dansksproget "Folkealmanak", hvis titelblad her gengives. Foruden en kalender indeholdt almanakken bl.a. resolutionen fra partidagen $i$ Flensborg i 1902, hvor de danske nordslesvigeres ret til en folkeafstemning om gransen anerkendtes. Fra Robert Huhles genudgivelse.

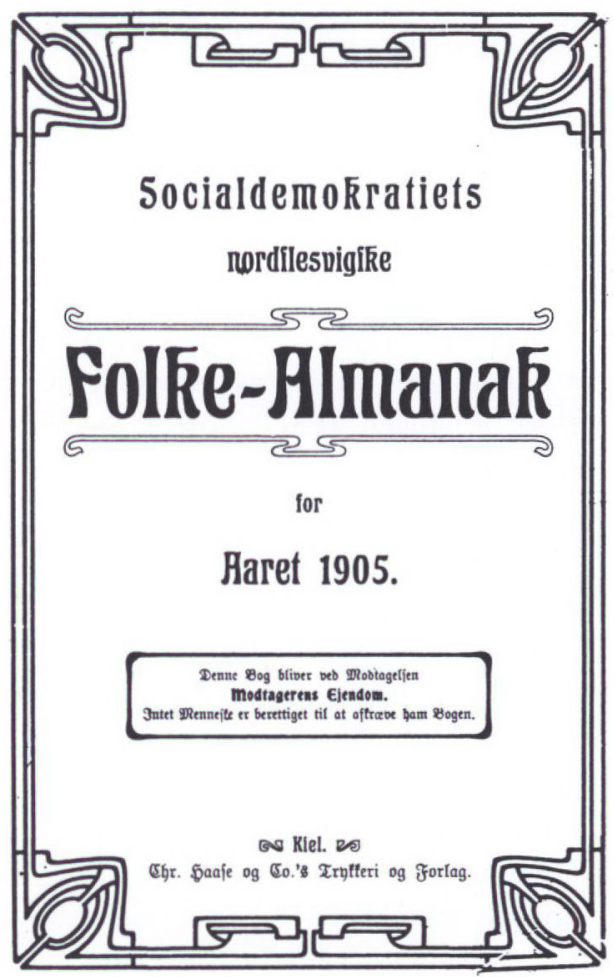


anerkendte man, at de danske sønderjyder havde en ret ifølge Pragfredens $§ 5$ til en fri afstemning om det statslige tilhørsforhold. Resolutionen vendte sig også imod den nationale undertrykkelse og forpligtede Socialdemokratiet til at bekæmpe denne. Samtidig indeholdt resolutionen dog også et punkt om, wat det er Socialdemokratiets opgave at oplyse proletarerne i det danske folk om socialismen under fuld anerkendelse af deres nationale rettigheder og at vinde dem for klassekampen til erobring af den politiske magt«.

Resolutionen afspejlede dermed en dobbelthed $\mathrm{i}$ socialdemokraternes forhold til den danske bevægelse: man ville gerne støtte den i kampen mod undertrykkelsen, men samtidig ville man gerne vinde de danske arbejdere for partiet. I de følgende år blev den dansksprogede agitation da også intensiveret med udgivelsen af »Socialdemokratiets nordslesvigske Folkealmanak « fra 1904 og med kvartalsskriftet "Det røde Postbud « fra 1905. Under valgkampen i 1906 efter redaktør Jessens død søgte Socialdemokratiet endvidere at arrangere et fællesmøde med det danske socialdemokratiske parti om det nordslesvigske spørgsmål. Da det var umuligt at få lokaler i Nordslesvig, hvor også de danske forsamlingshuse var lukkede for socialistiske møder, skulle fællesmødet finde sted i Frederikshøj lige nord for Kongeågrænsen. Det blev imidlertid aflyst, fordi det danske søsterparti sagde fra, antagelig af udenrigspolitiske grunde. ${ }^{8}$

\section{Den danske bevægelse og arbejderne indtil 1908}

Den nordslesvigske arbejderklasse blev - med rette - anset for helt overvejende dansksindet. Alligevel blev den kun i meget ringe omfang inddraget i det politiske og kulturelle arbejde, som foregik $i$ det net af danske foreninger, der siden 1880 var blevet spundet ud over Nordslesvig. Sprogforeningen, Vælgerforeningen og Skoleforeningen samt de lokale foredrags- og gymnastikforeninger domineredes $i$ stedet af gårdmandsstanden, i medlemskreds og fremfor alt i ledelse. ${ }^{9}$

Der var både økonomiske og sociale grunde hertil. For de lavest lønnede udgjorde årskontingentet det meste af en dagløn, og den lange arbejdsdag på 10 timer nærmest umuliggjorde deltagelse $\mathrm{i}$ foreningslivet. Mange arbejdere var dertil afhængige af tysksindede arbejdsgivere. Oven i disse hindringer kom det mere uhåndgribelige, men dog stærkt følte skel mellem klasserne i omgangsmæssig henseende. Dette skel betød dog næppe overalt lige meget, sikkert mest i østkystens proprietæregne og i de rige marskområder, mindst i midtlandet.

Endnu langt op i 1890-erne vakte Socialdemokratiet ikke den store bekymring hos den danske bevægelses ledere. H.P. Hanssen vurderede efter partiets 
stagnation ved valget i 1893, at socialismen var færdig i Nordslesvig, og i 1897 advarede han sine københavnske venner imod kunstigt at fremkalde et socialdemokratisk spørgsmål i Nordslesvig ved at tale for meget om det. ${ }^{10}$

Året $\mathrm{i}$ forvejen havde hans eget blad »Hejmdal« dog bragt et læserbrev, hvor en anonym indsender under overskriften "En fare « påpegede risikoen for, at "småfolkene« sluttede sig til socialismen. Derfor var det vigtigt, at de bedrestillede undlod at vise socialt hovmod. Forskellen i dannelse var nu blevet så stor, at det gamle patriarkalske forhold mellem husbonde og medhjælpere afvikledes, men arbejdsgiveren burde dog fortsat yde sine folk de traditionelle småtjenester. Derimod afviste indsenderen, at de danske kandidater skulle tage sociale punkter med på deres valgprogram, for det ville være at blande sig i tysk indenrigspolitik. ${ }^{11}$

Forud for rigsdagsvalget i 1898 mente Vælgerforeningens bestyrelse det imidlertid nødvendigt at udsende et særligt opråb til arbejderne. I opråbet, der udsendtes i 5000 eksemplarer, appelleredes der kraftigt til den nationale enhedsfølelse, som burde overgå alle klasseskel, og der advaredes imod socialdemokraternes lokketoner: "Ligesom tyske agrarer mange steder i Nordslesvig har gjort forsøg på at forlede vore danske bønder til frafald fra den danske sag, således har tyske socialdemokrater også i den senere tid haft deres garn ude efter eder. Bønderne har bestemt afvist deres tyske standsfællers bejlen. Vi er overbeviste om, at I ligeså bestemt vil afvise de tyske socialdemokraters bejlen, thi arbejdere! de danske kandidater ved rigsdagsvalget er ikke repræsentanter for et parti eller for en klasse, de er reprosentanter for en befolkning ${ }^{12}{ }^{12}$

Den socialdemokratiske fremgang var dog denne gang meget beskeden, og i de følgende år 1898-1901 gav overpræsident von Köllers mindretalsundertrykkende politik den danske bevægelse andet at tænke på. Men forud for rigsdagsvalget i 1902 blev der på ny taget fat på problemet. Fisker Hans Chr. Petersen fra Blans offentliggjorde således et indlæg om danskheden og socialismen. Han ville ikke nægte, at han sympatiserede med socialdemokraterne: »Jeg skal ikke sige, hvis jeg, som vel ikke er arbejdsmand, men dog skal ernære mig med mine hænders gerning, boede i Danmark, da måske også jeg ville give socialisterne min stemme«. Men da der alligevel ikke ville blive valgt en socialdemokrat i 1. valgkreds Haderslev-Sønderborg, ville han i stedet opfordre til, at man stemte dansk: »Her bør vi alle holde sammen, hvad enten vi er store eller små. Skulder ved skulder må vi stå i vor nationale kamp«. ${ }^{13}$

Dansk kandidat var for første gang redaktør Jens Jessen fra »Flensborg Avis«. I en valgtale med titlen »Vore arbejdere« tog også han socialdemokraternes udfordring op. Det fremgik heraf, at Jessen var blevet stående i 1870ernes socialistforskrækkelse: »Hvis man spørger arbejderne, om de ønsker en sådan omvaltning af samfundet, at deres hjem opløses, og at alle voksne 
mennesker får plads i store friboliger, muligvis mænd og kvinder for sig, og børnene i fælles opdragelsesanstalter, så vil vistnok de fleste sige, at de foretrækker at have et eget hyggeligt lille hjem«. Talen bar også præg af, at Jessen nok vidste, hvad der var bedst for arbejderne. Således fremhævede han, at for store lønninger kunne føre til arbejdsløshed og dermed skade arbejderne selv. Dette kunne måske nok være rigtigt ud fra en nationaløkonomisk betragtning, men det var ikke med sådanne udtalelser, man vandt arbejderstemmer. Dertil behøvedes klare, sociale programpunkter, som Jessens forgænger Gustav Johannsen havde haft det, men sådanne fandtes ikke i Jessens tale. ${ }^{14}$ Ovennæunte fisker Petersen påstod da også senere: "... da Jessen blev opstillet, da kneb det mange steder med at få den lille mand med, man vidste jo at Jessen var en udpræget aristokrat . $^{15}$

\section{Årsmødet 1908 og Vælgerforeningens arbejdersekretariat}

Så længe redaktør Jessen var rigsdagsmand, kunne der ikke ventes initiativer fra den danske bevægelse i »arbejderspørgsmålet«. Imidlertid døde Jessen i 1906, og han efterfulgtes som rigsdagsmand og dermed som leder af den danske bevægelse af H.P. Hanssen.

Det slesvig-holstenske socialdemokratis intensiverede agitation efter 1902 (jvf. s. 292) vakte både bekymring og irritation i danske kredse. Det var nu blevet H.P. Hanssen klart, at den hidtidige passive danske politik $\mathrm{i}$ arbejderspørgsmålet måtte ændres til en aktiv. På det danske årsmøde i Rødding 13.14. juni 1908 skildrede han i sin tale, hvorledes den socialdemokratiske trussel var rykket nærmere ved det kort forinden afholdte landdagsvalg: »Hvem der som jeg i denne tid har siddet med kontrollisten ved valgbordet $i$ en af vore byer, vil have lagt mærke til, at mens de gamle arbejdere i regelen har stemt dansk eller tysk, har de unge i stor udstrækning stemt på de socialdemokratiske valgmænd. Mange vil have følt sig trykket af, at den gamle, hvidhårede fader stemte dansk, mens hans unge, raske søn stemte socialdemokratisk «.

H.P. Hanssen bekendte sig uden vaklen til den danske bevægelses politik: "Vi har altid med stolthed hævdet, at vi er en befolkning, og ikke et parti«. Men konsekvensen, han drog af denne opfattelse var ny: "Vi må derfor også $i$ tide søge at modvirke enhver partidannelse inden for vort lille folkesamfund. Men skal vi dette, er det ikke nok, at vi på alle tænkelige måder styrker den nationale samfundsfølelse. Det er nødvendigt, at vi tillige, med Centrum og polakker som mønster, optager et omfattende socialt arbejde, så ingen arbejder herefter finder sine økonomiske interesser bedre varetaget andetsteds« (Centrum var de tyske katolikkers parti). 
H.P. Hanssens forslag pd drsmedet $i$ Rodding $i$ juni 1908 om oprettelse af et arbejdersekretariat blev snart fulgt op af Valgerforeningen, hvis bestyrelse i oktober 1908 kunne bekendtgøre, at nu åbnede kontoret. Opråb $i$ Flensborg Avis 16.10.1908.

\section{Brelgexforeningen $\mathfrak{D p l y z :}$ ningsfoutor.}

$\mathfrak{F}$ e bag ben 16. Oltober aabnes "Rorbilesvigft 2Arbejberfetretariat" (Bælger. foreningen Dplysningstontor) i $\mathfrak{A a b e n r a a . ~}$

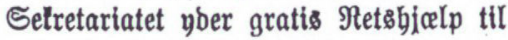
alle og entyoer $\mathfrak{i}$ etboert ben $\mathfrak{b}$ or $\mathfrak{g} e \mathfrak{r}$. lige $\Re$ et, 2 r bejoerforfitring lovgivningen, Tyendeloven, $\mathfrak{N a r i n g}$ retten, $\mathfrak{B}$ rnepltgten, anberfact forbolbet og For.

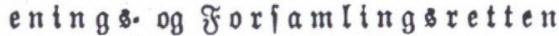
vebrarenbe Spørgamaal. Selretariatet $u b$.

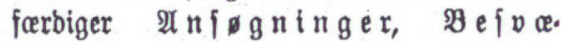
ringer og $\Re \mathfrak{l}$ a ger og voertager om fornobent og $i$ ben Ubftralning, Soven tillaber, at fore Sagerne for be tompetente Domftole.

Seltretariatet, ber lebe af cand. polit. Sr. R. Thomjen, bar Rontor $\mathfrak{t}$ Ilabenraa $i$ Mitael Jebjens (Babe $\mathfrak{R r}$ 4, frrfte Sal (veb Gavnen).

Rontoret er indtil vibere aabent guer $\mathfrak{M} a$ nbag og $\mathfrak{T}$ or $\operatorname{bag}$ fra 2 til 4 , Tirsbag og $\mathfrak{F}$ rebag fra 6 til 8 Efftermibbag.

Striftlige frorefpørgeler til Selretariatel bejpares jaa vibt muligt omgaaenbe.

Belgerforeningens Beftyrelje:

ร. $\mathfrak{R}$. Sabenboveb.

Nis $\mathfrak{R}$ is $\{$ en, Rorbborg.

Konkret foreslog H. P. Hanssen, at der i Vælgerforeningens regi blev oprettet et arbejdersekretariat, der vederlagsfrit skulle yde arbejdere (og andre) hjælp med at udfærdige ansøgninger, besværinger og klager til myndighederne og arbejdsgivere vedrørende arbejderforsikringsloven, foreningsretten, statsborgerforhold m.v. ${ }^{16}$ 
"Nordslesvigsk Arbejdersekretariat « begyndte sin virksomhed i Aabenraa i oktober 1908 med Kresten Refslund Thomsen som arbejdersekretær. Det behandlede årligt 450-650 sager, mest om arbejderforsikringsloven, invalidepension, veteranunderstøttelse, almindelig borgerlig ret og forholdet mellem arbejdere og arbejdsgivere. Med hensyn til sidstnæunte var det arbejdersekretærens politik at »ordne sagen i mindelighed «. I begyndelsen veg man dog ikke tilbage fra at føre retssager, men det holdt man senere op med på grund af de store omkostninger. Måske var retssagerne heller ikke så populære blandt Vælgerforeningens mange gårdmandsmedlemmer. ${ }^{17}$

Næsten samtidig med Vælgerforeningen oprettede den dansksindede socialdemokrat Chr. Mathiesen på mere privat basis et arbejdersekretariat i Flensborg, der også tog sig af arbejdsanvisning. Under navn af »Dansk Oplysningsog Arbejdsanvisningskontor (Arbejdersekretariat) « bestod det ligesom Vælgerforeningens sekretariat frem til den første verdenskrigs udbrud i $1914 .^{18}$

\section{Debatten efter årsmødet i 1908}

H.P. Hanssens tale på årsmødet i Rødding løste op for en hidtil uset bred debat om »arbejderspørgsmålet « $i$ »Hejmdal« og "Flensborg Avis«, hvor nu også mange arbejdere gav deres mening til kende.

Hovedspørgsmålet $\mathrm{i}$ debatten blev hurtigt, om der skulle dannes en forening for dansksindede arbejdere i Nordslesvig, og hvilke opgaver en sådan forening $i$ givet fald skulle have. Tanken om en dansk arbejderforening fremsattes første gang af "En flensborgsk arbejder«, der nævnte arbejdsanvisning som en vigtig opgave for foreningen. Dette gør det til et rimeligt gæt at udpege ovennæunte Chr. Mathiesen som den anonyme forslagsstiller. ${ }^{19}$

Under alle omstændigheder fandt ideen hurtigt tilhængere. Den mest uforbeholdne tilslutning kom fra væver Th. Kaufmann i Tråsbøl. Han rettede stærke anklager mod arbejdsgiverne, først og fremmest gårdmændene, for socialt hovmod: "... desværre ser man såre mange eksempler på, at arbejdsgiverne behandler deres arbejdere som laverestående væsner, hvem der anvises opholdssted sammen med det umælende kvæg. Tysksindede naboer og bekendte beder man til gilde hos sig, men ens egne danske tjenestefolk formener man adgang til familiekredsen«. Bl.a. derfor var en arbejderforening nødvendig, og initiativet måtte nu komme fra arbejderne selv. Foreningen skulle sørge for, at der i højere grad blev aflønnet $i$ forhold til arbejdsindsatsen, den skulle fremme oplysning, ædruelighed og sparsommelighed blandt arbejderne og $i$ det hele taget lære dem at stole på sig selv.

Derudover skulle arbejderforeningen ifølge Kaufmann sikre arbejderne stør- 
Vever Thomas Kaufmann (1877-1971) fra Bovrup var den dansksindede smo$k$ drsstands forende talsmand $i$ drene op imod den forste verdenskrig. I laserbreve og på de nationale drsmoder fremsatte han gang pd gang krav om en storre arbejderreprasentation $i$ de danske foreningers ledelse samt om udstykning af storre ejendomme til husmandsbrug. Hans erindringer "Minder og tanker" fra 1962 er en vigtig skildring af levevilkảrene i samfundets lavere sociale lag. Fot. fra o. $1910 i$ Bovrup-Varnas sognearkiv.

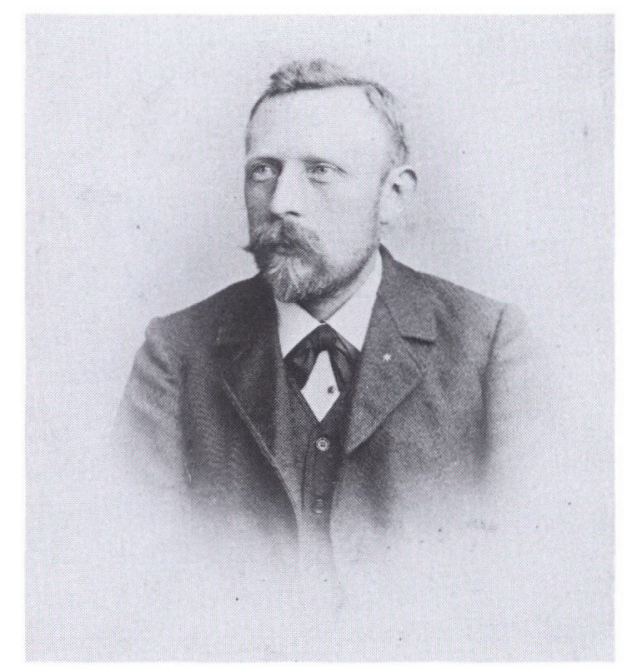

re indflydelse på den danske bevægelses politik, hvor "småkårsfolk« nu var henvist til en "statistrolle«. I Vælgerforeningens tilsynsråd sad kun to repræsentanter (ud af 25) fra de lavere sociale lag, nemlig foruden Kaufmann selv fisker Hans Chr. Petersen fra Blans. Egentlige arbejdere var der ingen af. Det måtte der ændres på. Kaufmann påpegede, at gårdmandsstandens samfundsmæssige frigørelse havde fundet sted under mottoet $» F r e m$, bondemand, frem «, nu måtte slagordet være $» F r e m$, arbejder, frem ${ }^{20}{ }^{20}$

Helt på linje med Kaufmann var »En alsisk landarbejder«. Også han understregede klasseskellenes barske realitet: "Standsforskellen lader sig ikke udviske eller overbygge, den lader sig ikke engang skjule eller tildække. Den er der, og den ses af enhver ... gårdmændene kommer sammen og holder deres gilder for sig, og småfolk gør ligeså.$^{21}$

Andre fortalere for en arbejderforening var ikke så radikale, hverken i samfundssynet eller i opfattelsen af, hvad der skulle være foreningens opgave. Peter Mink, maskinbygger fra Haderslev, påpegede, at andre stænder havde dannet interesseorganisationer, og nu måtte det være arbejdernes tur. Mink afviste ikke, at en arbejderforening skulle varetage materielle opgaver - konkret nævnte han oprettelse af en syge-, begravelses- og lånekasse - men hovedsagen var dog for ham dygtiggørelsen af medlemmerne "på håndens som på åndens grund«. Derigennem kunne arbejderen lære at kende sit eget værd, og det "trællepræg, som hænger eller skal hænge på arbejderen« ville helt udviskes. Og en »dygtig, kvik og oplyst « arbejder ville med rette kunne kræve og få en højere løn. 
En oplyst arbejderstand ville også være i den danske bevægelses interesse; foreningen skulle $\mathrm{i}$ det hele taget dannes på et afgjort nationalt grundlag. For at få skred i sagen foreslog Mink, at der blev afholdt et møde, eventuelt på Folkehjem i Aabenraa, hvor oprettelsen kunne ske. ${ }^{22}$

Faktor J.A. Sorensen fra "Flensborg Avis«s trykkeri mente ligeledes, at oplysning måtte være foreningens hovedopgave, mens de sociale krav bedst varetoges af de eksisterende fagforeninger, der ikke alle var socialistiske. ${ }^{23}$ Endnu mere forsigtig var en anonym indsender med initialerne H.C.H. Han fandt, at Vælgerforeningens arbejdersekretariat i første omgang var tilstrækkeligt. Skulle man senere beslutte sig for en arbejderforening, var arbejdersekretæren den rette til at samle materiale og sikre, at arbejderforeningen blev oprettet i samklang med de øvrige danske organisationer. ${ }^{24}$

Direkte modstander af en dansk arbejderforening var M.C. Petersen fra Aabenraa. De nationale opgaver blev fuldt ud varetaget af de eksisterende danske foreninger, hvis tilbud arbejderne kunne udnytte bedre. Og til at gennemføre sociale krav ville foreningen blive for lille. Skulle man opnå forbedringer for medlemmerne, kom man ikke uden om strejker, men som kamporganisation ville en dansk arbejderforening være den socialdemokratiske fagbevægelse klart underlegen. Det var naivt at tro, at en arbejderforening, der skulle støttes af alle dansksindede, kunne fremme arbejderinteresser - »En sådan anskuelse vidner ikke om megen kendskab til arbejderbevægelsen «, sluttede indsenderen, der antagelig var socialdemokrat. ${ }^{25}$

Socialdemokratiet var også som parti modstander af en dansk arbejderforening. I "Socialdemokratiets nordslesvigske Folkealmanak « for 1909 imødegik en flensborgsk partifælle oprettelsen af en dansk arbejderforening med argumenter, der svarede til M.C. Petersens. ${ }^{26}$

Men også inden for den danske bevægelse var der modstandere af planen om en arbejderforening. "Flensborg Avis", der efter redaktør Jessens død lededes af Ernst Christiansen, støttede oprettelsen af arbejdersekretariatet og foreslog dannelsen af arbejderboligforeninger, en udstykningsforening og en social understøttelsesforening. Avisen ønskede også forbedringer i tyendets boligforhold og $\mathrm{i}$ dets omgang med gårdejerne. Men en arbejderforening var næppe nødvendig: "En dansk arbejderforening, som søger at højne arbejderstanden og at sprede national oplysning, vil vel nok kunne gøre nogen gavn, men det turde være tvivlsomt, om der hertil udkrævedes nogen særlig forening for arbejdere«. Det gjaldt først og fremmest om, at der blev slået bro over klasseskellene. ${ }^{27}$

Der blev da heller ikke oprettet nogen dansk arbejderforening i denne omgang. Det møde, som P. Mink ønskede afholdt, fandt ganske vist sted den 27. september 1908. H. P. Hanssen var inviteret til mødet for at hjælpe til med 
udformningen af vedtægterne. Det viste sig imidlertid, at der ikke var basis for en forening. Fisker Petersen fra Blans advarede f.eks. imod, at de danske nordslesvigere delte sig efter klasser, og som det fremgik af debatten, var forventningerne til foreningen ret forskellige. Måske har også H.P. Hanssen stillet sig afvisende. ${ }^{28}$

\section{Diskussionen på og efter årsmødet 1911}

Mødets negative udfald satte en foreløbig stopper for den sociale diskussion. I årene 1909 og 1910 hørte man ikke meget til »arbejderspørgsmålet«. Sparekassebogholder P.A. Callo fra Rødding agiterede dog i 1909 for større sparsommelighed blandt tjenestefolk, og han fik oprettet en tyendespareforening i Skodborg. Callø fremhævede stærkt, at tjenestefolk havde mulighed for at spare sammen til en lille ejendom: »Landarbejderklassen er ikke klasse længere, end den selv vil. Vejen er fri. Den dreng, som vogter bondens køer, kan selv blive bonde og holde køer og dreng til at passe dem ${ }^{29}{ }^{29}$ Heri fik han medhold af Chr. Mathiesen fra Flensborg. ${ }^{30}$ Desuden skrev Th. Kaufmann i 1910 et indlæg om standsforskellen. Han påstod her, at de sociale skel gik dybere end de nationale, og han fortsatte felttoget mod standshovmodet, der særlig var grelt i Haderslev Østeramt, hvor man på almindelige bondegårde kunne høre tjenestefolk omtale deres arbejdsgivere som wherren $«$ og wruen ${ }^{3 !}{ }^{3 !}$

Først på årsmødet $\mathrm{i} 1911 \mathrm{i}$ Toftlund kom der igen rigtig gang $\mathrm{i}$ den sociale debat. ${ }^{32}$ Arbejderne var nu selv de udfarende. Fisker Petersen fra Blans havde således ordet hele tre gange. Først udtrykte han tilfredshed med arbejdersekretariatets virke og ønskede, at store ejendomme blev udstykket til husmandsbrug. Dernæst begrundede han arbejderstandens manglende repræsentation $\mathrm{i}$ de nationale foreningers ledelse med fraværet af overskydende tid og penge. Endelig fremførte han, at de nordslesvigske arbejdere var ringere stillet end deres klassefæller i Danmark, hvor en tjenestekarl blev hjulpet til eget hjem. Alligevel erklærede han, at den nordslesvigske arbejder ville fylde sin plads $\mathrm{i}$ den nationale kamp.

Maskinbygger Mink fra Haderslev understregede som i 1908 vigtigheden af, at arbejderne nåede frem til en erkendelse af sit eget værd, og at de bedrestillede imødekom arbejderne ved at overlade dem flere tillidsposter i de danske organisationer. Mest radikal var også denne gang Th. Kaufmann. Han sagde atter, at de sociale skel bundede dybere end de nationale, og han fastholdt dette synspunkt trods protester. Kaufmann mente nok, at en dygtig arbejder kunne komme frem i Nordslesvig, men det var kun individuelle løsninger: "Skal forholdene blive bedre, hvad jeg tror de bliver engang, må der en 


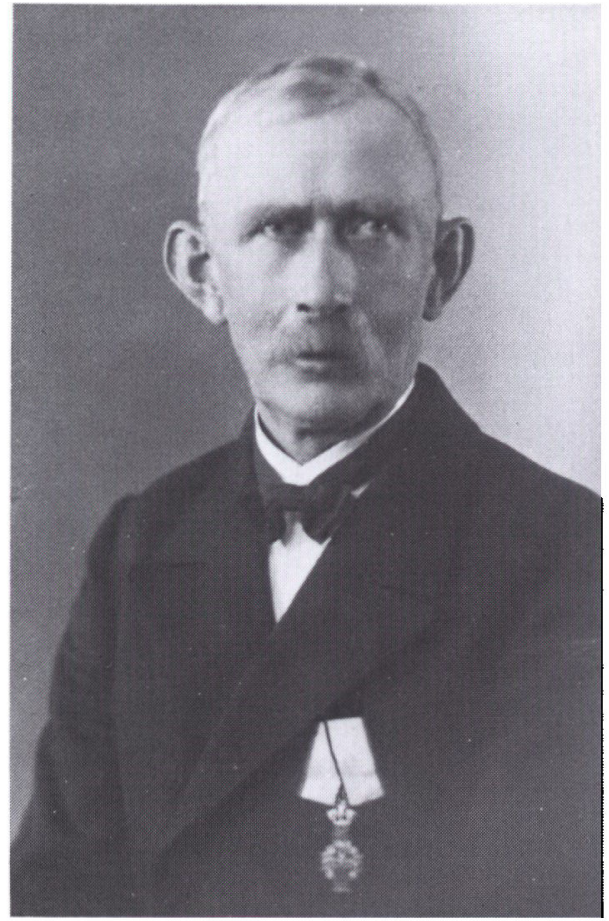

Maskinbygger Peter Mink (1871-1948) fra Haderslev var ikke så radikal $i$ samfundssyn og sociale krav som Kaufmann. Han slog $i$ stedet pd, at hjalp til selvhjalp matte vare vejen frem for den nordslesvigske arbejder. Disse tanker blev grundlaggende for Dansk Arbejderforening, som Mink blev formand for fra starten i november 1911. Fot. i Haderslev byhistoriske arkiv.

hel omændring af samfundsorganisationen, særlig [af] ejendomsforholdet til jorden, til«, sagde han. En ret radikal udtalelse, stedet og tilhørerne taget i betragtning.

Der lød også nu mere eller mindre modvillige røster. Landdagsmand og gårdejer H.D. Kloppenborg-Skrumsager hævdede således, at den sociale fordeling ikke var videre ulige i Nordslesvig, og det var ikke rigtigt at sige, at arbejderne blev undertrykt. "Vi er alle arbejdere«, mente han!! Frimenighedsprest Thade Petersen fandt ikke, at man ved valget af foreningsledelser skulle spørge efter stand, men alene efter dygtighed.

Heller ikke "Flensborg Avis" var i sin kommentar til årsmødetalerne videre imødekommende over for arbejdernes synspunkter. Drøftelsen af arbejderspørgsmålet havde efter bladets mening ikke bragt nyt frem: »Det er de samme personer og de samme ord, der går igen. ... Men det bringer ikke løsningen et hanefjed nærmere, når der mødes op med nogle fortærskede vendinger om det ...«. Sådant bidrog kun til at øge klassehadet. ${ }^{33}$ "Hejmdal " gav "Flensborg Avis« ret $i$, at der ikke var kommet nye momenter ind $i$ diskussionen, men 
spørgsmålet var så væsentligt, at det ikke gjorde noget. Det viste ikke mindst udviklingen i Flensborg, som måtte være den danske bevægelse en påmindelse om at være lydhøre over for arbejdernes synspunkter - så fik den sydlige konkurrent den ${ }^{34}$

Modstanden på mødet og i pressen fik fisker Petersen til at opgive troen på, at arbejderspørgsmålet kunne løses i samarbejde med de bedrestillede. ${ }^{35}$ Her fik han følgeskab af C.H. Nohns fra Spandet. "Nej«, skrev denne, "vil arbejderne søge at forbedre deres stilling, må de selv tage sagen i hånd. Men for at kunne det med udsigt til held, er det nødvendigt, at de slutter sig sammen i forbund «. ${ }^{36}$

Hovedtemaet i den fortsatte debat blev dog ikke oprettelsen af en arbejderforening, men udstykningssagen. P.A. Callø lagde for med kort og godt at fastslå: "Giv de nordslesvigske arbejdere adgang til Nordslesvigs jord, og det sociale spørgsmål i Nordslesvig er løst«. Det kunne ske, fordi den dygtige og sparsommelige arbejder kunne erhverve og klare sig på en lille landejendom, hvis han fik lidt støtte. Det burde ske af nationale grunde. Callø ønskede også, at arbejdernes krav om bedre repræsentation i ledelsen af den danske bevægelse blev imødekommet. ${ }^{37}$

Gårdejer Marten Refslund Poulsen, Skovgård, der var tidligere formand for Fælleslandboforeningen for Nordslesvig, mente ikke, at udstykning var nødvendig. Der var små ejendomme nok, som sparsommelige karle kunne erhverve med lidt hjælp. Refslund Poulsen nævnte, at gårdejerne gennemgående var villige til at gøre deres nationale pligt og hjælpe med kaution. Udstykning ville derimod dels blive for dyr, dels virke nationalt skadelig derved, at der ville blive købt færre mindre ejendomme fra tysksindede. ${ }^{38}$

Gårdejer Th. Thomsen, Toghale og A. Nissen, Nr. Løgum, var også skeptiske med hensyn til deciderede udstykninger, men de gik ind for, at der ved frastykninger fra gårde blev givet tillægsjord til de bestående mindre brug, så at disse blev store nok til at kunne ernære en familie, uden at manden skulle gå på lønarbejde. Også de mente, at en flittig karl kunne arbejde sig op. ${ }^{39}$

Fisker Petersen nuancerede den ofte fremsatte påstand om den sparsommelige arbejders mulighed for at blive ejer af et husmandssted med jord. De løst ansatte landarbejdere, daglejerne, var nemlig meget dårligt stillet. Med en løn på 6-700 mark årligt foruden kosten hos arbejdsgiverne, var det med de nuværende priser på livsfornødenheder umuligt at spare nok op. Mange daglejere måtte tilmed gå arbejdsløse i månedsvis om vinteren, og maskinerne gjorde mange af dem overflødige. Derimod kunne tjenestekarlene nok spare op, og gennem udstykninger burde der tilvejebringes brug på 3-5 tdr. land god jord, som de kunne købe. Et sådant husmandssted kunne nok ernære en 
familie, og det var ikke større, end at manden kunne påtage sig lidt lønarbejde i landbrugets højsæson.

Petersen ville ikke bestride, at der var små ejendomme nok, men hvad skete der med dem? De blev opkøbt af kapitalstærke gårdejere, der lagde jorden ind til deres egne marker og lejede huset ud til arbejderfamilier. Den, som i forvejen ejede jord, kunne altid let skaffe midler, og over for dette måtte arbejderne give op. ${ }^{40}$

Kaufmann gav Petersen ret og fremhævede den nationale fordel, som var forbundet med, at arbejderne blev på landet. Han vendte sig lidenskabeligt mod påstande om, at »bønderfolks« børn var bedre end arbejderbørn som arbejdskraft, og han fandt det uværdigt, når karle og landarbejdere skulle gå tiggergang for at få hjælp til at købe ejendom. Han bestred, at det skulle være så ligetil at få kaution hos gårdmændene, som Refslund Poulsen gav det udseende af. ${ }^{41}$

I et andet indlæg uden for udstykningsdebatten redegjorde Kaufmann yderligere for sit samfundssyn: "Der findes i dag i vor samfundsbygning værelser, hvor et mindretal af samfundets medlemmer kan bo lunt inden døre, men langt den største del af medlemmerne må bo i den store øde hal, hvor regnen kan sive ned og en isnende kold trækvind blæser ind ad vinduer og døre«. Kaufmann troede dog ikke, at det sociale spørgsmål lod sig løse i »en håndevending«. Tiden var endnu ikke inde til en nomfattende samfundsreform «. Socialismen var han modstander af. Den var for materialistisk, "men efter min mening undergraver man bedst kapitalens magt ved at drage menneskene bort fra materialismen $i$ det hele taget, ved at åbne folks øjne for et idealt livssyn«. Specielt vendte Kaufmann sig mod socialisternes afvisning af kristendommen. ${ }^{42}$

Selv om Kaufmann således i sine fremtidsvisioner var ret moderat, bærer hans ordvalg alligevel umiskendeligt præg af, at han - og sikkert andre fra de lavere sociale lag - var blevet mere radikale $i$ deres krav til de velstående nordslesvigere.

\section{Dansk Arbejderforening for Nordslesvig}

Diskussionen efter årsmødet døde ud hen i juli måned 1911. Spørgsmålet om en arbejderforening var kun blevet berørt sporadisk. Alligevel blev en sådan oprettet senere hen på året, uden forudgående debat eller agitation i pressen. En mindre kreds samledes den 13. november og stiftede »Dansk Arbejderforening for Nordslesvig, Haderslev Afdeling". Foreningen fik straks 50 mænd og kvinder som medlemmer. Af bestyrelsen havde kun formanden, maskinbygger 
Peter Mink, markeret sig i den offentlige debat, mens næstformanden, arbejdsmand Jørgen Rasmussen, sekretæren, møllebygger Anton Houborg og kassereren, typograf Chr. Lageri, hidtil ikke havde deltaget.

Vedtægterne bekendtgjorde: „Foreningens formål er at varetage arbejdernes interesse ved gennem samarbejde og sammenhold at løfte og gavne dens medlemmer på håndens som på åndens område, til gavn og glæde for den enkelte og til held og lykke for vort folk og vor nationale sag«. Formuleringen afspejlede altså især Minks tanker (jvf. s. 306), og sociale programpunkter var ikke udspecificeret. Derimod blev det i vedtægterne slået fast, at foreningen ikke skulle befatte sig med fagforeningsanliggender. Medlem kunne »enhver uberygtet dansksindet mand eller kvinde blive, der selv henregner sig til arbejderstanden «. Det var meningen, at der ud over Nordslesvig skulle dannes afdelinger svarende til denne forste i Haderslev. ${ }^{43}$

Bladenes kommentarer var nærmest køligt afventende. "Flensborg Avis« frygtede også nu, at arbejderne ved oprettelsen af den nye forening ville blive udsondrede fra det øvrige danske foreningsliv, og at klasseforskellene dermed ville blive uddybet. ${ }^{44}$ "Dannevirke«, der ikke hidtil i større omfang havde deltaget $\mathrm{i}$ den sociale debat, fremhævede foreningens nationale karakter, men

Blandt de forste medlemmer af Dansk Arbejderforenings Grdstenafdeling var ikke overraskende vaver Kaufmann. Medlemskort $i$ hans privatarkiv pa LA, pk. 15.

\section{Dautf $\mathfrak{A}$ (rbejoerforentitg \\ for Rorbilesvig \\ (aibeling Sraasten) \\ ren}

\section{Mededemábenis}

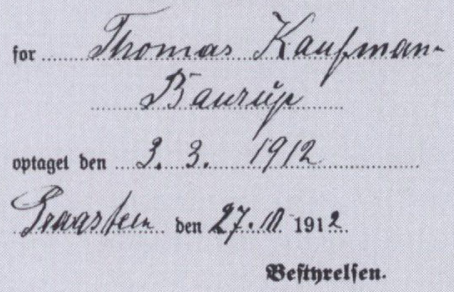


ville ellers afvente foreningens videre virke. ${ }^{45}$ Det samme mente "Hejmdal«, der dog var så venlig at ønske held og lykke med forsøget. ${ }^{46}$

En uforbeholden tilhænger af den nye forening var derimod ikke overraskende Th. Kaufmann, der så vidt vides ikke havde været direkte impliceret i dens tilblivelse. Han forventede af Dansk Arbejderforening, at den først og fremmest virkede for oplysning, sparsommelighed og ædruelighed. Men den skulle også varetage sociale interesser, nemlig påtale arbejdsgiverovergreb, hindre at de nordslesvigske arbejdere trængtes ud af polakker og østpreussere og føre lønforhandlinger. Deciderede lønkampe skulle foreningen imidlertid holde sig fra. Men frem for alt skulle Dansk Arbejderforening virke for den nationale sag. ${ }^{47}$

Den foreløbige reservation blandt lederne af den danske bevægelse forsvandt dog efter det første offentlige foreningsmøde i Haderslev den 26. november. Det indrømmedes både af "Flensborg Avis« og direktør Christensen fra Slotsvandmøllen, som talte på mødet. Dette besøgtes ifølge »Flensborg Avis« af 60-70 personer, mens »Hejmdal« angav deltagerantallet til godt 100 . Her fremlagde sekretæren foreningens politik. Hovedmålet var at samle alle nordslesvigske arbejdere $\mathrm{i}$ kampen for danskheden og hindre deres overgang til Socialdemokratiet. Gennem oplysning skulle arbejderne hjælpes fremad, også til større indflydelse i de nationale foreninger. Hjælp til selvhjælp var det vigtigste middel hertil. Dansk Arbejderforening skulle også sørge for, at arbejderne tog del i de politiske valg. Af sociale opgaver næunte Houborg kun mægling ved arbejdskonflikter.

Næstformanden Jørgen Rasmussen vendte sig imod tyske blade, der havde hævdet, at foreningen stod i opposition til »højskoleånden« inden for den danske bevægelse. Det forholdt sig stik modsat.

Foruden direktør Christensen blev Dansk Arbejderforening også budt velkommen af redaktør Anders Lebeck og Fælleslandboforeningens formand, gårdejer P.J. Refshauge. Med sit første møde havde den nye organisation alt $i$ alt opnået at blive accepteret af den danske bevægelse, men det var sket ved at nedtone de sociale krav til fordel for de nationale opgaver. ${ }^{48}$ Derfor kunne den heller ikke overvinde Socialdemokratiets skepsis. ${ }^{49}$

Efter Haderslevafdelingens etablering blev der gjort forsøg på at oprette andre afdelinger i Nordslesvig. I midten af december 1911 slog et tilløb i Skodborg fejl, hvorimod det lykkedes at få etableret en arbejderforening $i$ Gråsten i marts 1912, øjensynligt på væver Kaufmanns initiativ. Afdelingen begyndte med 15 medlemmer, dens første formand var kusk Chr. Lausen. Den blev aldrig særlig stor og var ikke meget aktiv. ${ }^{50}$ Større held havde Dansk Arbejderforening på Haderslev nas. Til det stiftende møde i maj 1912 i Hyrup var der således mødt henved 100, og heraf indtrådte straks 34 i lokalafdelingen, 
der fik landmand Jørgen Petersen fra Halk til formand. Medlemmerne fandtes mest i Halk og Øsby sogne. ${ }^{51}$

Fra begyndelsen af maj 1913 kendes endvidere afdelinger i Tyrstrup, Jels, Vedsted og Hoptrup, men de var ikke levedygtige i længden. ${ }^{52}$ Det var derimod Møgeltønderafdelingen fra slutningen af maj samme år - måske fordi den var protegeret fra højeste sted, nemlig af grev O.D. Schack på Schackenborg, som havde taget initiativet til det stiftende møde, og som selv indtrådte i foreningen! Afdelingen startede med 27 medlemmer. $^{53}$

Medlemsudviklingen var i de enkelte afdelinger således: ${ }^{54}$

\begin{tabular}{lrrrrrrrrr}
\multicolumn{3}{c}{ Haderslev } & \multicolumn{2}{c}{ Haderslev næs } & \multicolumn{2}{c}{ Møgeltønder } & \multicolumn{2}{c}{ Gråsten } \\
nov. 1911 & 50 & maj 1912 & 34 & maj 1912 & 27 & mar. 1912 & 15 \\
dec. 1911 & $80-90$ & dec. 1912 & 136 & okt. 1913 & 47 & sep. 1912 & 26 \\
apr. 1912 & 100 & feb. 1913 & 140 & & & & dec. 1912 & 29 \\
nov. 1912 & 117 & jan. 1914 & 135 & & & & & \\
okt. 1913 & 140 & & & & & & & & \\
mar. 1914 & 140 & & & & & & & & \\
aug. 1914 & 149 & & & & & & & &
\end{tabular}

Forud for krigsudbruddet 1914 nåede foreningen næppe højere end 300-350 medlemmer. Interessen for en dansk arbejderforening var altså, når arbejderklassens omfang tages $\mathrm{i}$ betragtning, ret begrænset, hvad også de mange ustabile afdelinger vidner om.

På det politiske felt markerede Dansk Arbejderforening sig ved valgene. Forud for rigsdagsvalget $i$ januar 1912 udsendtes et opråb til arbejderne med opfordring til at stemme på de danske kandidater, og der blev afholdt et valgmøde, der samlede omkring 100 deltagere. Kommissionær N.P. Petersen fra Aabenraa hilste her oprettelsen af arbejderforeningen med glæde, men han frarådede den at agitere i midtlandet og på vestkysten - sthi der var forholdene endnu sådan, at den største bonde kunne sidde i værelse sammen med tjenestefolkene«. Han fremhævede endvidere, at den danske bevægelse med sine organisationer og med sin rigsdagsmand gjorde mere for arbejderne end Socialdemokratiet. I forlængelse heraf udtalte møllersvend Houborg, foreningens sekretær, at Dansk Arbejderforening ville »føre de tabte danske arbejdere tilbage « - underforstået fra Socialdemokratiet. ${ }^{55}$

Dansk Arbejderforening udsendte også forud for landdagsvalget i maj 1913 et opråb, som var underskrevet af samtlige afdelingers bestyrelser. Det fremgår heraf, at foreningen appellerede bredt til arbejdere og mindre selvstændige. Blandt underskriverne var således 9 håndværkssvende, 7 arbejdere, 5 landmænd, 2 kuske, en håndværksmester, en vognmand, en kulhandler og en fisker. ${ }^{56}$ 
Melodi: Jeg elsker de gronne Lunde.

$V i$ satte hinanden stavne

Og modtes til festligt Lag

Saa lad os forst nu da navne,

Hvad samlet os har $i$ Dag.

Vi dannet har en Forening,

Af danske Kvinder og Mand,

Der rede til Daad og Handling,

Staar gjordet med Svard ved Land.

Ja det at vi Kamp vil fore,

Det siger jo ikke stort,

Dog straks, man skal faa at hore,

Hvad vi os til Maal har gjordt.

Saa vist, er der meget at gare, Om Arbejdsmand skal naa frem,

Sit Liv, paa den Vis, at fore,

Saa Arbejd kan adle dem.

De Krav, der stilles er mange,

Dog det tor man stole paa,

At ingen skal se os bange,

Om ogsaa vi er de Smaa.

Vi har en Gerning at gøre,

For vort Hiem, vort Folk og Land.

Se her vil vi Kampen fere

Og kampe til sidste Mand.
Naar derfor nogen vil rove, Hvad vi har faaet kart, Mod det vil vi Krafter prove, Det beste, som vi har lart.

Ja var vort Hjem kun en Hytte

Med Stue, men ingen Sal;

Vi vil det dog ikke bytte,

For Slottet med hojen HaI.

Foruden vort Hjem, vi tanker

Paa Hjemmene vidre ud,

Naar Natten sin Skygge sanker,

Over Landet, vi fik of Gud.

Ja dybest $i$ Hjertegrunden

Nost Hj'm. vi elsker vort Land.

Og ej alene med Munden,

Gir Lofte da Arbejdsmand,

Af Evne, at ville bygge

Sit Hjem, sit Land og sit Folk.

Gud give os dertil Lykke,

Til Held for os selv, vort Folk.

Til Dansk Arbejderforenings forste offentlige møde den 26. november 1911 i Haderslev havde P. Mink digtet ovenstående sang $i$ den bedste nationale kampstil. Fra Kaufmanns privatarkiv på LA, pk. 15.

På det økonomisk-sociale område indskrænkede Dansk Arbejderforening sig til rene hjælp til selvhjælps-foranstaltninger. I februar 1912 opstod tanken om en kreditforening for medlemmerne, og i januar 1913 kunne den realiseres. Formålet var at støtte medlemmers køb af mindre landejendomme. Kapitalen skulle tilvejebringes ved tegning af andele á 25 mark, så det har formodentlig været småt, hvad der kunne ydes af lån. I samme ånd som kreditforeningen oprettedes en spareforening i Haderslevafdelingen. ${ }^{57}$

Haderslevafdelingen var $\mathrm{i}$ det hele taget den mest aktive. Den arrangerede således adskillige foredrag. H.P. Hanssen talte f.eks. om den moderne arbejderbevægelse, P.A. Callø om socialismens idé og teori og landdagsmand Nis Nissen om den kristelige og socialistiske arbejderbevægelse i Tyskland 18701914. Også ved valg af talere og emner udgjorde Dansk Arbejderforening altså et kompromis mellem det nationale og sociale! Haderslevafdelingen 
afholdt derudover fester, skiveskydning, dilettant, udflugter og deslige af mere selskabelig karakter. På det felt var afdelingen på Haderslev næs også godt med, ellers var den mere passiv. ${ }^{58}$

Alt i alt kan det om Dansk Arbejderforening for Nordslesvig siges, at dens virke afspejlede de tanker, som formanden Peter Mink i 1908 havde gjort sig. Den skulle være og var en forening for arbejdere, til fremme af deres danske sindelag, selvrespekt og oplysning. Deciderede, kollektive sociale krav til de mere velbjergede nordslesvigere formulerede foreningen ikke, hverken lønkrav eller krav om jord til husmænd. Derimod søgte man i bedste liberalistiske ånd at fremme »hjælp til selvhjælp«, bl.a. gennem sparsommelighed, uddannelse og ædruelighed.

Kravet om udstykning rejstes dog atter af væver Kaufmann i november 1913 i »Flensborg Avis«. Han foreslog her, at arbejderforeningen skulle samle materiale, der kunne bevise, at der var brug for udstykning. Det ser dog ikke ud til, at der skete mere i sagen. Endnu engang blev Kaufmann skuffet, og i februar 1914 nedlagde han sit hverv som medlem af Valgerforeningens tilsynsråd. Han havde tilsyneladende opgivet troen på, at udstykningstanken kunne fremmes gennem samarbejde med den danske bevægelse. ${ }^{59}$

\section{Sammenfatning}

Ifølge H.P. Hanssen prægedes det nordslesvigske samfund $\mathrm{i}$ årene forud for den første verdenskrig af en sund balance mellem antallet af selvstændige og lønmodtagere, ligesom der forekom en betydelig social mobilitet. Men også dengang betød betragterens egen placering i samfundet meget for vurderingen af de sociale forhold. De forskellige indlæg, som fremkom fra arbejderside $i$ debatten om »arbejderspørgsmålet « i den danske presse, viser således, at man her ikke opfattede forholdene som den rene idyl. Der blev givet udtryk for, at der også i Nordslesvig fandtes en dyb social kløft, både økonomisk og i den daglige omgang, og standshovmodet var stadig en realitet.

Der fandtes således et socialt konfliktpotentiel, som kunne true med at sprænge den danske nationale enhedsfront. De nordslesvigske arbejdere havde, $i$ hvert fald på landet, ved valgene markeret deres danske sindelag ved altovervejende at stemme på den danske bevægelses kandidater. Derimod var arbejderne ikke i nævneværdigt omfang blevet inddraget i det danske foreningsliv, der især var skabt og ledet af gårdmændene. Da Socialdemokratiet fra slutningen af 1890 'erne begyndte at vinde frem og forstærke agitationen i Nordslesvig, opstod der derfor blandt lederne af den danske bevægelse frygt for, at arbejder- 
ne ville forlade det nationale sammenhold til fordel for det klassebetonede, sådan som det i 1880'erne var sket i Flensborg.

Frem til 1908 førte den danske bevægelse imidlertid en ret passiv politik i warbejderspørgsmålet«. Man nøjedes stort set med at udsende manende appeller til arbejderne om ikke at svigte de danske kandidater ved valgene. Men på årsmødet i Rødding i juni 1908 fremsatte den nyvalgte rigsdagsmand H.P. Hanssen forslag om oprettelse af et arbejdersekretariat inden for Vælgerforeningen, og om efteråret blev planen realiseret.

Dette skridt kaldte en gruppe af dansksindede arbejdere frem, som ikke ønskede at slutte sig til Socialdemokratiet. I stedet ville de med dannelsen af deres egen arbejderforening på et dansk grundlag forene deres nationale og sociale engagement. Dette lykkedes dog ikke før 1911, hvor "Dansk Arbejderforening for Nordslesvig « blev oprettet. Foreningen havde imidlertid vanskeligt ved at slå igennem og nåede før 1914 kun at få etableret tre levedygtige afdelinger med tilsammen 300-350 medlemmer. I overensstemmelse med formanden, maskinbygger P. Minks, tanker var Dansk Arbejderforening overvejende en oplysningsforening. Nogen social kamporganisation blev den aldrig, og det var måske hovedårsagen til den beskedne tilslutning.

Andre, især væver Th. Kaufmann og fisker H.C. Petersen, stillede mere vidtgående sociale krav som en større arbejderrepræsentation $\mathrm{i}$ de danske foreningers ledelse og udstykning af større ejendomme til husmandsbrug. Mens Dansk Arbejderforening med sin klare nationale profil og stærke moderation i de sociale krav overvandt den animositet, som ved dens oprettelse havde gjort sig gældende blandt flere af de mere velbjergede i den danske bevægelse, mødte Kaufmanns og Petersens krav afvisning, i hvert tilfælde i udstykningssagen. Kun sparekassebogholder P.A. Callø viste åbent forståelse for denne idé, som jo også i sin yderste konsekvens anfægtede den danske bevægelses fundament, gårdmandsstandens uafhængige jordbesiddelse. Men måske var denne ramme for den nationale kamp i færd med at blive for snæver?

\section{NOTER}

1. H.P. Hanssen: De danske Sønderjyder, SJy Årb 1913, s. 43.

2. H.P. Hanssen: Fra Kampaarene, II, Kbh. 1929, s. 195.

3. H. Schultz Hansen: Det nordslesvigske landbrug og den danske bevægelse 1880-1914, Åbenrå 1985 , spec. s. $18 \mathrm{f}$.

4. Samme: Det industrielle miljø i Sønderborg 1875-1914, SJy Årb 1987, s. $35 f$.

5. Fr. v. Jessen: Haandbog i det nordslesvigske Spørgsmaals Historie, Kbh. 1901 s. $282 \mathrm{f}$ og samme: Haandbog i det slesvigske Spørgsmaals Historie, I, Kbh. 1938, s. 169.

6. Se nærmere herom i min bog om danskheden som politisk og kulturel bevægelse i Sydslesvig ca. 1840-1918 (udk. 1990).

7. Dorrit Andersen: Da socialismen kom til Sønderborg, SJy MSkr 1973, s. 270. 
8. Om Socialdemokratiets Nordslesvigpolitik: Gerd Callesen: Die Schleswig-Frage in den Beziehungen zwischen dänischer und deutscher Sozialdemokratie von 1912 bis 1924, Apenrade 1970, s. 1541. Dorrit Andersen: Socialdemokrati og dansknational bevæegelse. Omkring det slesvigholstenske SPD's 1902-resolution, Historie, ny rk. XIII, 1979, s. 123-44 (med gengivelse af resolutionen).

9. H. Schultz Hansen: Det nordslesvigske landbrug og den danske bevægelse 1880-1914, s. 179193.

10. H.V. Clausen: Nordslesvig 1863-93, SJy Årb 1894, s. 129. Harald Jørgensen (udg.): To Ungdomsvenner, Aabenraa 1962, nr. 156.

11. Hejmdal (herefter: Hjd.) 25.2.1896, se også 7.3.1896.

12. LA, Vælgerforeningens arkiv nr. 21, Sager vedr. valg 1890-1913.

13. Hjd. 12.12.1902 og Flensborg Avis (herefter Fl.A.) sa. dato.

14. Jens Jessen: Valgtaler 1902, Flensborg 1902, s. 17-23.

15. LA, H.P. Hanssens arkiv nr. 83, brev fra H.Chr. Petersen 5.10.1909. I Petersens hjemamt Sønderborg steg socialdemokratiets valgerandel fra 1,8 til 3,4\% i 1902 (Lassen anf. arb. s. 449).

16. H.P. Hanssen: Fra Kampaarene II, s. 126-134.

17. LA, Valgerforeningens arkiv nr. 45, Nordslesvigsk arbejdersekretariat, alm. sager vedr. sekretariatets virksomhed, årsberetninger m.v. 1909-13.

18. Dorrit Andersen: National og social solidaritet. Chr. Mathiesen - en arbejderfører i granselandet. Festskrift til Johan Hvidtfeldt, Kbh. 1978, s. 1-22. Jørgen Nielsen: Arbejder i danskhedens tjeneste, Aabenraa 1987, s. 46-52.

19. Fl.A. 8. og 9.7.1908.

20. Hjd. 21.7. og 11.8.1908.

21. Hjd. 4.8.1908.

22. Hjd. 10.8. og 1.9.1908.

23. Fl.A. 1. og 3.9.1908.

24. Fl.A. 12.7.1908.

25. Hjd. 4.8.1908.

26. Socialdemokratiets nordslesvigske Folkealmanak 1909, Kiel 1908.

27. Fl.A. 1.9.1908.

28. LA, H.P. Hanssens arkiv nr. 79, brev fra P. Mink 9.9.1908. Hjd. 19.6.1911.

29. Hjd. 10.9.1909, Fl.A. 28.4.1910.

30. Fl.A. 18.6.1910.

31. Fl.A. 8.8.1910.

32. Hjd. 12.6 og Fl.A. 13.6.1911.

33. Fl.A. 21.6.1911.

34. Hjd. 19.6.1911.

35. Sst.

36. Hjd. 22.6.1911.

37. Hjd. 16.6.1911.

38. Hjd. 24. og 26.6.1911.

39. Hjd. 30.6.1911 og Fl.A. 5.7.1911.

40. Hjd. 30.6. og 20.7.1911.

41. Fl.A. 9.7.1911.

42. Fl.A. 30.6. og 2.9.1911.

43. Fl.A. og Hjd. 16.11.1911.

44. Fl.A. 17.11.1911.

45. Citeret i Fl.A. 17.11.1911.

46. Hjd. 16.11.1911.

47. Fl.A. 20.11.1911.

48. Fl.A. og Hjd. 28.11.1911.

49. FI.A. 2.12.1911.

50. LA, Th. Kaufmanns arkiv nr. 15, sager vedr. Dansk Arbejderforening, brev fra P. Mink 14.2.1912, medlemskort 3.3.1912. Hjd. 5.3.1912, Fl.A. 20.2., 5.3. og 19.12.1912. 
51. FI.A. 19.5.1912.

52. Fl.A. 15.5.1913. Chr. Lageri: Arbejderbevægelsen, i: A. Kirkeby og E. Schack: Sønderjylland som det er, Kbh. 1920, s. 335-341.

53. Fl.A. 27.5.1913. O.D. Schack: Grænsesind, Kbh. 1970, s. 47.

54. Fl.A. 13.1., 5.3., 19.5. og 19.12.1912, 27.5. og 14.10.1913. Flensborg Avis: Nordslesvig 1912, Flensborg 1913, s. 79. LA Schl-H, Abt. 309, regeringen i Slesvig, nr. 24470, Dänische Agitation 1912-13, ber. fra landråderne i Haderslev 1.4. og Aabenraa 28.9.1912. Haderslev byhistoriske arkiv, A 828, regnskabsbøger for Dansk Arbejderforening for Nordslesvig, afdelingerne i Haderslev og på Haderslev nas.

55. Fl.A. 9. og 11.1.1912.

56. Fl.A. 15.5.1913.

57. Fl.A. 20.2.1912, 7.1. og 3.2.1913.

58. Haderslev byhistoriske arkiv, A 828, regnskabsbøger for de to afdelinger. Sammesteds: Haderslev rådstuearkiv, acta 52,3, Dansk Arbejderforening for Nordslesvig 1911-14.

59. Fl.A. 1.11.1913. LA, Kaufmanns arkiv nr. 15, brev fra Martin Simonsen 3.2.1914 og udat. brev fra Kaufmann til landsarkivar Gribsvad. 